\title{
Impact of Environmental Pollution on Respiratory System of Human and Animals in Angul and Talcher Industrial Areas, Odisha, India: A Case Study
}

\section{Das L and Patri $\mathbf{M}^{*}$ \\ Department of Zoology, Ravenshaw University, Cuttack-753003, India}

*Corresponding author: Manorama Patri, Department of Zoology, Ravenshaw University, Neurobiology Laboratory, School of Life sciences, Cuttack-753003, Odisha, India, Tel: 8763642486; Email: mpatri@ravenshawuniversity.ac.in

\section{Research Article}

Volume 2 Issue 4

Received Date: June 19, 2019

Published Date: July 10, 2019

DOI: $10.23880 /$ izab-16000162

\section{Abstract}

Industrial growth has been a national issue with leading risk factor towards human health and the environment. The major air pollutants including particle pollution has different toxicological impacts on animals and human health. Polycyclic aromatic hydrocarbon (PAHs) present in particle is known to induce significant respiratory, reproductive and neuropsychiatric complications. To investigate the effect of major particle pollutants, sources of emission, and their impact on human health and to check the toxicological/pathological impact of particulate matter (PM) containing Benzo[a]pyrene like toxicants on increasing rate of respiratory and reproductive diseases. The percentage of different trace element in the atmosphere was measured by monitoring air quality index through high volume sampling method and Atomic Absorption Spectroscopy in Angul-Talcher areas. Effect of intratracheal and intraperitonial administration of $\mathrm{B}[\mathrm{a}] \mathrm{P}$ during PND 28 were examined on adult male Wistar rats after 15 days and 30 days of post exposure. Chest X-ray reports of human (Aged 20-60) were collected for acute respiratory diseases, asthma, conjunctivitis and bronchitis. Study showed monthly variation in the elemental content of the flyash samples including B[a]P. Histopathology of lungs and testis showed morphological changes in $\mathrm{B}[\mathrm{a}] \mathrm{P}$ treated rats as compared to the control. Similarly chest X-ray report showed different respiratory symptoms in human residing near Angul-Talcher industrial areas. The indices for PM are above the standard and mostly at dangerous level in TTPS. Thermal emissions are important in causing respiratory and other diseases. The present findings may contribute to building up evidences for environmental exposure and health effects in man and animals.

Keywords: Environmental Pollution; Particulate Matter; Angul-Talcher Area; B[a]P; Respiratory Diseases

Abbreviations: PAHs: Polycyclic Aromatic Hydrocarbon, PM: Particulate Matter, PND: Post-Natal Days, NALCO: National Aluminium Company, TTPS:
Talcher Thermal Power Station, PSU: Public Sector Undertaking, OSPCB: Odisha State Pollution Control Board, CPCB: Central Pollution Control Board, MCL: 


\section{International Journal of Zoology and Animal Biology}

Mahanadi Coalfield Limited, PCB: Polychlorinated Biphenyls, COPD: Chronic Obstructive Pulmonary Disease, CEPI: Comprehensive Environmental Pollution Index, ARD; Acute respiratory diseases.

\section{Introduction}

Pollution from industrial and municipal sources, exploitation by industries and other commercial activities has led to severe environmental degradation and depletion of natural resources like land, forests and various common property sources for fuel wood, fodder and water $[1,2]$. In India, air pollution is restricted mostly to urban areas, where automobiles are the major contributors, and to a few other areas with a concentration of industries and thermal power plants. Exposure to air pollutants is a major problem in industrial areas, which has a serious toxicological impact on human health and the environment $[3,4]$. The major sources of air pollution in the country are industries (toxic gases), thermal power plants (fly ash and sulphur dioxide), and motor vehicles (carbon monoxide, particulate matter, hydrocarbons and oxides of nitrogen) [4,5]. The incidence of respiratory diseases in most of the major cities in India has also increased considerably due to increasing traffic, rapid economic development and industrialisation and higher levels of energy consumption over the years [6,7]. All these industrial activities have caused significant degradation of environmental quality whereas AngulTalcher area is considered as one among the most polluted areas of India. This area of Odisha is a highly polluted industrial belt having one of the largest aluminium company (NALCO), well known for Talcher Coal Mines and huge deposits of coal in the area. It is like a bridge between Western and Coastal halves of Odisha. The significant feature of Angul and Talcher area is that there are 5 PSUs besides 4 Large Scale Industries within which provides a strong evidence that episodes of air pollution aggravate respiratory illness [8]. There are at present eight big coal mines working in the Angul-Talcher area. The area has been declared as the most environmentally sensitive area due to rapid industrialisation in the last two decades.

Particle pollutants having solid and liquid particles in air forming particulate matter (PM) is one of the most critical pollutants in terms of its impact on air quality and is also the most common pollutant in the industrial areas. Fine particulate matter in the ambient air is implicated in a variety of human health issues throughout the globe [79]. The PM2.5 is particulate matter having 2.5 micrometers or less in diameter has a devastating effect on human and animal's health acting as one of the major air pollutants $[5,9]$. The maximum permissible limits laid down by Central Pollution Control Board (CPCB) for annual average concentration in ambient air $(70 \mu \mathrm{g} / \mathrm{m} 3)$ in sensitive areas, $140 \mu \mathrm{g} / \mathrm{m} 3$ in residential areas and 360 $\mu \mathrm{g} / \mathrm{m} 3$ in industrial areas [10,11]. The concentrations of these particulate pollutants often exceeded the corresponding values; where PM2.5 was the most serious particle in these areas. Environmental chemicals, such as polychlorinated biphenyls (PCB) and polyfluoroalkyl chemicals have been found to be positively associated with cardiovascular and respiratory diseases suggesting that the environmental chemicals may be related to various risk factors. Large size particle with a diameter above 50 microns $(\mu)\left(1 \mu=10^{-6}\right.$ meter $)$ are collectively visible in the air and settle down quickly, so that they are not a long term pollution hazard [10]. Particles of size ranges from 50-0.01 $\mu$ diameter are of most significant air pollutants. As per statistics, nearly 90 millions of people in India including 6 billions of children are suffering from behaviour related diseases like Autism Spectrum Disorders, Alzheimer's, Parkinson's and cardiovascular diseases etc, are mostly seen in the district of Talcher which may be due to rapid industrialization and wide spread mining activities in the area [11-13].

The fly ash containing PAHs e.g. Benzo[a]pyrene, $(\mathrm{B}[\mathrm{a}] \mathrm{P})$ in Angul-Talcher industrial area are mainly generated due to the incomplete combustion of organic materials (e.g. coal, oil, petrol, and wood), natural and anthropogenic processes [10]. Industrial emission, extraction from power plant generally predominates; nevertheless, some particulate matter in the environment originates from natural sources such as pollen, spores, bacteria, coal deposits, volcanic eruption, plant and animal debris. Major human made sources of PAHs include, coal gasification and liquefying plants, cigarette smoking, combustion by products from incinerators, motor vehicles residential heating carbon black, coal-tar pitch and asphalt production, coke and aluminium production, catalytic cracking towers and related activities in petroleum refineries as well as and motor vehicle exhaust [11]. Among various complex mixtures of gases include indoor and outdoor particles in the environment which produces adverse health effects like asthma and chronic obstructive pulmonary disease (COPD) highly prevalent chronic inflammatory diseases of the airways [14-16]. Although several approaches aim to target these respiratory diseases, but the impacts of PAHs like chemical compounds on human health, triggering and inducing reproductive diseases has received less attention. 


\section{International Journal of Zoology and Animal Biology}

According to previous studies the health of the individuals living in Angul and Talcher area is deteriorating; and the statistics shows recurring contagious diseases, alarmingly increasing life-style diseases, increasing rates of diseases affecting the growing child $[12,13]$. CPCB, developed a Comprehensive Environmental Pollution Index (CEPI) in the country to address complex problems of pollution. CEPI is based on the concentration of five major air pollutants including particulate matters (PMs), sulfur dioxide $\left(\mathrm{SO}_{2}\right)$, nitrogen dioxide $\left(\mathrm{NO}_{2}\right)$, carbon monoxide $(\mathrm{CO})$, and ozone $\left(\mathrm{O}_{3}\right)$ in the air. Waste generation due to the operation and expansion of mining and industrial activity also had a serious negative impact on the environment resource $[14,15]$. Diseases of the respiratory system included: acute respiratory diseases (ARD) defined as upper other acute lower respiratory' infections and pneumonia and asthma [15-17]. Some environmental issues also have been created due to the establishment of large industries in different areas of our country as well as in Odisha State. The impacts of pollutants in industrially developed areas are in the range of minimal to severe causing health hazards to humans and animals [17]. The reports in the previous literature mainly concentrate on the respiratory symptoms of young children [18]. The effects of exposure to flyash containing $\mathrm{B}[\mathrm{a}] \mathrm{P}$ on both animals as well as humans living in this industrial areas like Angul-Talcher was less addressed in present scenario. Therefore, it is of great importance to address the problem, particularly its toxic effects on animal and human health as a basis for environmental guidelines and standard exposure effects assessment in the field of air pollution in Angul-Talcher area [19].

$\mathrm{B}[\mathrm{a}] \mathrm{P}$, is a common environmental pollutant and potent neurotoxicants which is cosmopolitan in nature easily enters the body and gets deposited in the adipose tissue and can cross blood brain barrier. $\mathrm{B}[\mathrm{a}] \mathrm{P}$ has endocrine disrupting chemical properties ultimately interfere in the normal physiological environment directly or indirectly and a keen of interest among several researcher to work [20]. B[a]P and other soot particles are direct skin irritants. Hence, the impact of PAHs containing $\mathrm{B}[\mathrm{a}] \mathrm{P}$ on human health depends mainly on the length and route of exposure, the amount or concentration of PAHs one is exposed to, as well as the relative toxicity of these neurotoxicant $[17,20]$. High levels of pollutant mixtures containing $\mathrm{B}[\mathrm{a}] \mathrm{P}$ have resulted in symptoms such as breathing problems, asthma-like symptoms, and lung function abnormalities, eye irritation, nausea, vomiting, diarrhoea and confusion [21]. It was also investigated specific effects of $\mathrm{B}[\mathrm{a}] \mathrm{P}$ on the origin and development of asthma bronchiole, due to the impact of air pollution in critically polluted industrial clusters, Angul-Talcher area [22,23].

Effects of air pollutants on living organism will not only be limited to the human and animal health but also include the status of whole environment $[23,24]$. Studies on the relationship between air pollution and reducing species diversity clearly show the detrimental effects of environmental contaminants on the extinction of animals and plants species $[24,25]$. Air suspended toxicants like PAHs at the high concentrations cause vulnerability to many diseases and also cause reproductive effects in animals [26,27]. Moreover, numerous scientific data have demonstrated that fine particle pollutants cause premature death in people with heart and/or lung disease including cardiac dysrhythmias, nonfatal heart attacks, aggravated asthma, and decreased lung functions [27]. Particles of smaller size, PM 2.5 reach the lower respiratory tract and thus have greater potential for causing the lungs and heart diseases [28]. The size of particle pollutants is directly associated with the onset and progression of the lungs and heart diseases [29]. Different geographical conditions, global climate changes, and the environmental variations affect the human health and the environment including the animal life. In the present study, we have focused on the effects of exposure to environmental pollutants like flyash containing $\mathrm{B}[\mathrm{a}] \mathrm{P}$ and other particulate pollutants like trace element on respiratory and reproductive system of adult Wistar rats.

\section{Study Areas (Description)}

The Angul-Talcher area is situated $150 \mathrm{~km}$ away from state capital of Odisha the Bhubaneswar, and lies between latitudes $20^{\circ} 37^{\prime} \mathrm{N}$ to $21^{\circ} 10^{\prime} \mathrm{N}$ and longitudes $84^{\circ} 53^{\prime} \mathrm{E}$ to 85o 28'E. Angul-Talcher area falls in the 'Brahmani River Basin' which is an inter-state river basin. Angul-Talcher region is present with $1813 \mathrm{~km}$ of coal bearing area and is one of the major industrial zones in the State of Orissa and also in India. Due to the vast mineral deposits in the catchment area, availability of water and good infrastructure are conducive for industrialization in the river basin of Brahmani with a catchment area of 4235.38 sq.km, in Angul district and its tributaries i.e. the Singhara, the Tikra and the Nandira etc. The population in this region is exposed to high concentrations of particulate matter pollutants with aerometric diameter < $2.5 \mu \mathrm{m}$, that are higher than those observed any other part of Odisha. Talcher in Angul district possess the largest resources of coal and fly ash containing higher concentrations of $(\mathrm{B}[\mathrm{a}] \mathrm{P})$ in Talcher thermal power plant 
area. Talcher is present on the bank of river Brahmani and Angul town is present near National highways. The South Eastern railway passes through Talcher town starting from Nirgundi Railway station to Angul. This railway connection also reaches the coastal region of Orissa. Now Talcher is connected to Sambalpur in western region by railway line. Angul-Talcher industrial area is now very well connected by railway line and national high ways. This industrial area also gets enough water from river Brahmani and Mahanadi for its all factories and industries. The Talcher coal mines were started functioning from the year 1923. Around $500 \mathrm{sq} \mathrm{km}$ of area in Talcher has plentily available of coal for power generation. There are at present eight big coal mines working in the Talcher area. The coal of Talcher is now used for many industries like paper, textile, cement in this region.

This area is home to a large number of thermal-based power plants and coal mines, the Angul-Talcher cluster was ranked seventh among 88 critically polluted industrial regions of the country based on a CEPI score by the CPCB in 2009. The Odisha State Pollution Control Board (OSPCB) is set to conduct a study to assess the impact of industrial pollution in Angul-Talcher area. The pollution board also finalising the details of the framework of the epidemiological study which will look into the effect of pollutants on the local population. However, in the last five years, the environmental conditions have improved as the pollution levels have showed a dip. The atmospheric temperature in AngulTalcher during day soars nearly to $44^{\circ} \mathrm{C}$ to $46^{\circ} \mathrm{C}$ in summer months. The operational coalfields of MCL and Thermal Power Plants of NTPC have enormously added to the environmental pollution. A lot of ash generated throughout these operations within the coalfield, created severe environmental hazard in air, water and land, inflicting serious diseases to the labour and therefore the inhabitants. The most well-known PAH, B[a]P, is just the beginning of our understanding of the components of these mixtures. The impact of PAHs pollution is also severe during this belt with incidence of white spots in the body, incurable skin infections and lumps of dead skin square measure increasing among the population Map 1.

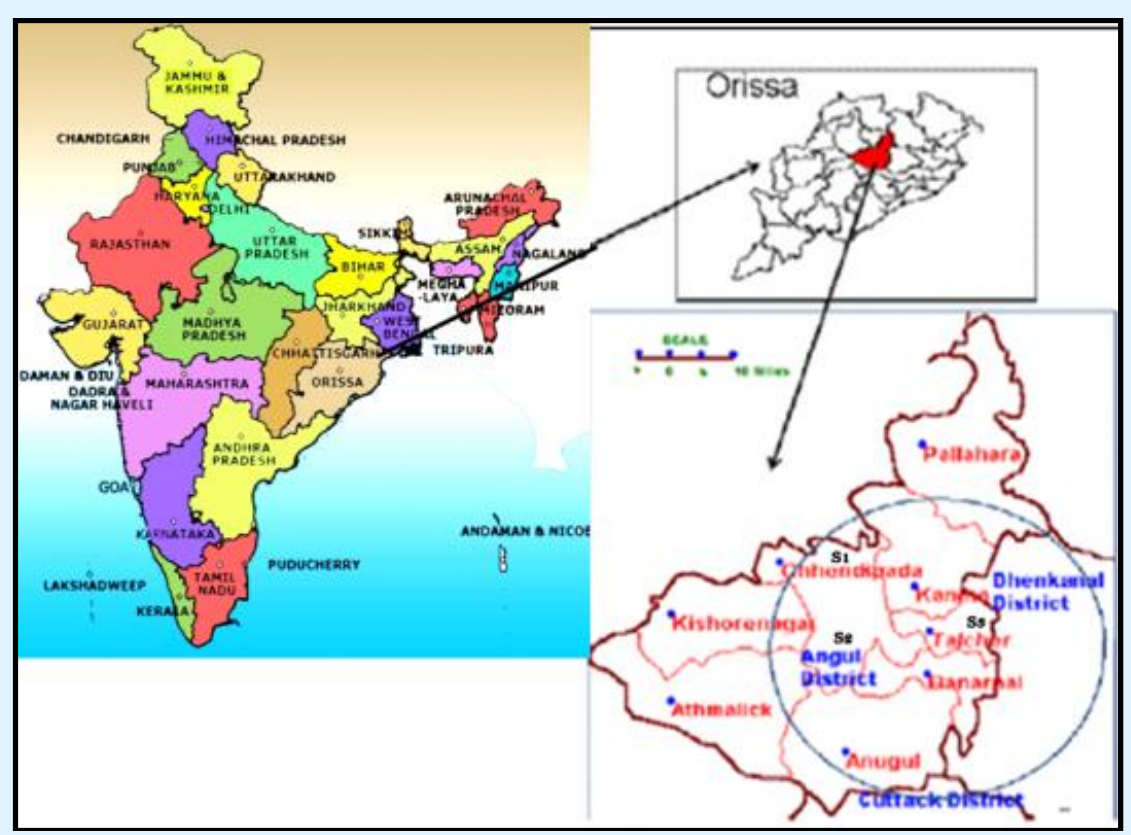

Map 1: Showing Angul-Talcher industrial area, Odisha, India and three sampling stations (S1 Chhendipada, S2 Angul District and S3 Talcher) [18].

\section{Sample Collection and Analysis}

Air measurements: Air pollutant samples (gaseous and particulate matter) were collected within a $30 \mathrm{~m}$ radius, between the hours of 10:00 am-2:00 pm, from January2010 to December, 2017 at the three sampling points (Figure 1). Field surveys of Angul-Talcher industrial area 
of Odisha were conducted during the (2011-2017) around Talcher Thermal Power Station (TTPS). Air of TTPS area was monitored by high volume sampler with flow rate $\left(1.1 \mathrm{~m}^{3} / \mathrm{min}\right)$ with respect to total suspended particulates.

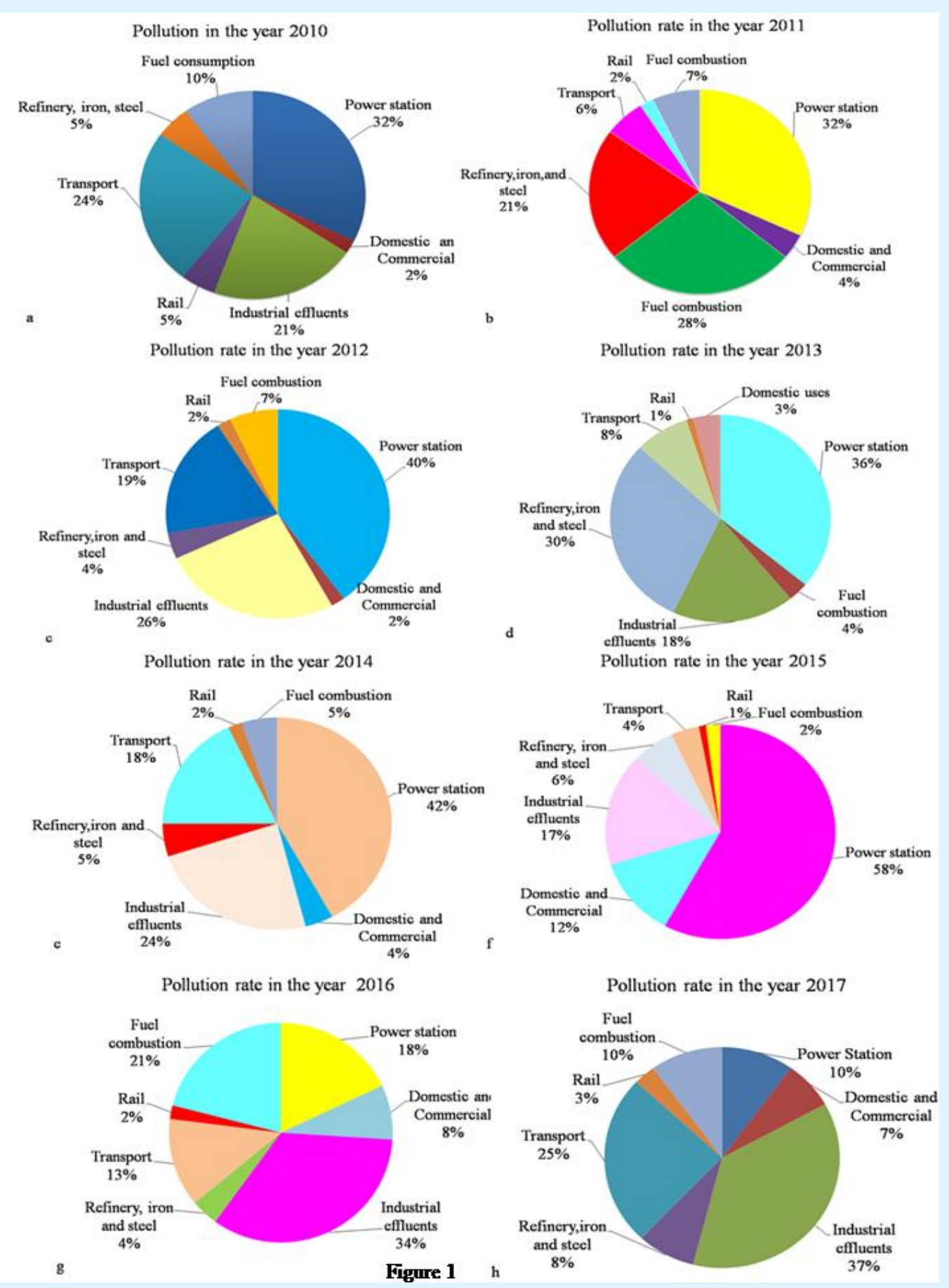

Figure 1: Pie chart showing air quality data and rate of pollution due to industrial and man-made activities in AngulTalcher area during the year (2010-2017) indicating the percentage of pollution level (Figures 1a-1h). 


\section{International Journal of Zoology and Animal Biology}

In this study, airborne dust samples, $\mathrm{B}[\mathrm{a}] \mathrm{P}$ content in the flyash samples and also the concentration of different trace elements were measured using Atomic absorption spectroscopy, and PM2.5 using the high-volume air (HVA) sampler model TCR. The suspended particulates were trapped on a glass-fibre filter paper and the total amount of these during sampling period expressed as $\mathrm{kg} / \mathrm{m} 3$ air. The concentration of $\mathrm{B}[\mathrm{a}] \mathrm{P}$ in the environment measured through practical quantisation (PQL), $0.01 \mathrm{mg} / \mathrm{L}$ by calorimetrically.

\section{Chemical Analysis of Fly ash Samples in the Atmosphere}

The major constituents such as $\mathrm{B}[\mathrm{a}] \mathrm{P}, \mathrm{SiO}_{2}, \mathrm{Al}_{2} \mathrm{O}_{3}$, $\mathrm{Fe}_{2} \mathrm{O}_{3}, \mathrm{MnO}, \mathrm{MgO}, \mathrm{K}_{2} \mathrm{O}, \mathrm{Na}_{2} \mathrm{O}, \mathrm{P}_{2} \mathrm{O}_{5}$, and loss of ignition were determined by rapid method following [20]. The concentrations of various trace elements in fly ash like $\mathrm{Pb}$, $\mathrm{Zn}, \mathrm{Cu}, \mathrm{Cd}, \mathrm{Ni}$, Co $\left(\mu \mathrm{g} / \mathrm{m}^{3}\right)$ etc were measured by Atomic absorption Spectroscopy (Perkin Elmer, Model 5000) at different sampling points $(\mathrm{mg} / \mathrm{kg})$ in Angul-Talcher industrial area.

\section{Experimental Animals}

Male Wistar rat (Rattus norvegicus) 5-day-old pups were obtained from the animal house of Ravenshaw University, Cuttack. They were maintained in home cages with normal laboratory chow and water ad libitum at $24^{\circ} \mathrm{C} \pm 1^{\circ} \mathrm{C}$ on a $12: 12$-hr light/dark cycle. The experiments were approved by the Institutional Animal Ethics Committee.

- Phase 1: The adult Wistar rats into three experimental groups. First group of rats $(n=6)$ were intratracheally administered with B[a]P (25 mg/animal) for 5 days in a week upto 15 days (lower dose). The second group $(n=6)$ were intratracheally administered with $\mathrm{B}[\mathrm{a}] \mathrm{P} \quad(50$ $\mathrm{mg} / \mathrm{animal}$ ) for 5 days in a week upto 30 days (higher dose). A control group $(\mathrm{n}=6)$ with DMSO $(<0.1 \%)$ run simultaneously in the same condition without any treatment to compare the effects of exposure to $\mathrm{B}[\mathrm{a}] \mathrm{P}$ on male adult wistar rat lungs.

- Phase 2: The adult Wistar rats were divided into three experimental groups. First group of rats $(n=6)$ were intraperitonially (i.p.) administered with B[a]P $(30 \mathrm{mg} / \mathrm{kg}$ wt) of animal each for 5 day in a week upto 15 days (lower dose). The second group $(\mathrm{n}=6)$ were intraperitonially administered with B[a]P (50 mg/animal) for 5 day in a week upto 30 days (higher dose). A control group $(\mathrm{n}=6)$ with DMSO $(<0.1 \%)$ run simultaneously in the same condition without any treatment to compare the effects of exposure to $\mathrm{B}[\mathrm{a}] \mathrm{P}$ on male adult wistar rat testis.

\section{Histological Processing}

The animals were anaesthetized and sacrificed and lungs and testis were isolated at $4{ }^{\circ} \mathrm{C}$ and subjected to post fixation in $4 \%$ paraformaldehyde for $24 \mathrm{hrs}$ followed by treatment with $10 \%, 20 \%$ \& $30 \%$ sucrose solution (Overnight/ for each solution). Serial cryo sectioning (Leica CM3050 S) of lungs and testis of rats were carried out following $20 \mu \mathrm{m}$ thickness for neuro morphological studies. After stained with Haematoxylin and Eosin (H\&E) alternate sections were taken and observed under requisite magnification in bright field phase (Olympus, BX43 F). Tissue sections were taken for histopathological analysis to measure the morphological variations in the $\mathrm{B}[\mathrm{a}] \mathrm{P}$ exposed groups (lower and higher dose) in comparison to control groups.

\section{Epidemiological Studies}

All volunteer participants $(n=12)$ were from TTPS area and they were recruited from two different sources: near TTPS 4-5 miles from the two selected pollutant monitoring stations (S2 and S3). Human respiratory illness for different villages of Angul-Talcher and many other districts nearby were studied with the far away villages from fixed pollution monitoring stations $(10 \mathrm{~km}$ distance) as control (S1). X-ray report studies were made for the tuberculosis, bronchitis, asthma and lung cancer cases out of the total number of cases recorded within age group (20-60). Individual reactions to air pollutants, the type of pollutant a person is exposed to, the degree of exposure, and the individual's health status were recorded. The design and procedure of the experiment were approved by the Institutional Ethical Committee on biomedical research on human subjects of SCB Medical College, Cuttack, Odisha, India in compliance with the guidelines of Indian Council of Medical Research (ICMR) (213/29.1.16). Written consents were obtained from all volunteer participants of Angul-Talcher area for the collection of chest X-ray report and analysis were done.

\section{Results}

\section{Chemical Analysis of Elemental Content in Fly Ash}

Angul-Talcher industrial area being one of the worlds's most polluted state of Odisha. Emission from Thermal Power Plant, coal burnt in powder form under a continuous flow of air. In such conditions, and at elevated 
temperature, the chemical reactions takes place on individual's granules or on partially agglomerated granules resulting in formation of a molt which finally gives rise to mixture of fly ash and bottom ash by using high volume sampler with flow rate $\left(1.1 \mathrm{~m}^{3} / \mathrm{min}\right)$. It has been shown through graphical representation that pollution rate has been constantly increasing from the year (2011-2017).

Table 1 showed the concentrations of various air pollutants at the sampling sites in different months of the year (2010-2017). The air quality data was measured and monitored in the environment at different sampling locations and sampling parameters are presented (Table 1). All samples were taken 3 times to minimize error from device readings. The highest concentrations of $\mathrm{B}[\mathrm{a}] \mathrm{P}, \mathrm{SiO}_{2}$, $\mathrm{Al}_{2} \mathrm{O}_{3}, \mathrm{MgO}, \mathrm{MnO}, \mathrm{Fe}_{2} \mathrm{O}_{3}, \mathrm{~K}_{2} \mathrm{O}, \mathrm{N}_{2} \mathrm{O}$ and $\mathrm{P}_{2} \mathrm{O}_{5}$ were measured $\left(\mu \mathrm{g} / \mathrm{m}^{3}\right)$ at different monitoring sites in different months. $\mathrm{B}[\mathrm{a}] \mathrm{P}$ was observed at the highest levels in June and November. These sites were also dominated by many industries, which use heavy duty generators that run on fossil fuels to power their equipment.

\begin{tabular}{|c|c|c|c|c|c|c|c|c|c|c|c|c|c|c|c|c|c|c|c|c|c|c|c|c|c|c|c|}
\hline \multirow{2}{*}{ Months } & \multicolumn{3}{|c|}{ B[a]P } & \multicolumn{3}{|c|}{$\mathrm{Sio}_{2}$} & \multicolumn{3}{|c|}{$\mathrm{Al}_{2} \mathrm{O}_{3}$} & \multicolumn{3}{|c|}{ MgO } & \multicolumn{3}{|c|}{ MnO } & \multicolumn{3}{|c|}{$\mathrm{Fe}_{2} \mathrm{O}_{3}$} & \multicolumn{3}{|c|}{$\mathrm{K}_{2} \mathrm{O}$} & \multicolumn{3}{|c|}{$\mathrm{Na}_{2} \mathrm{O}$} & \multicolumn{3}{|c|}{$\mathrm{P}_{2} \mathrm{O}_{5}$} \\
\hline & 1 & 2 & 3 & 1 & 2 & 3 & 1 & 2 & 3 & 1 & 2 & 3 & 1 & 2 & 3 & 1 & 2 & 3 & 1 & 2 & 3 & \begin{tabular}{l|l}
1 \\
\end{tabular} & \begin{tabular}{|l|l}
2 \\
\end{tabular} & 3 & \begin{tabular}{l|l}
1 \\
\end{tabular} & 2 & 3 \\
\hline \multirow{2}{*}{ Jan } & 60 & & 4 & 7 & & 5 & 25 & & 2 & 0 & & & 0 & & & 5 & & 0 & 0 & & 0 & 6 & 2 & 3 & 0 & 0 & 0 \\
\hline & 0 & & 8 & & & 6 & & & 69 & 48 & 59 & 67 & 40 & & 80 & ( & 63 & 75 & 86 & 55 & 88 & 20 & \begin{tabular}{|l|l|}
50 & 2 \\
\end{tabular} & 21 & 37 & 35 & 44 \\
\hline \multirow[t]{2}{*}{ 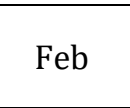 } & & & & & & & & & & & & & & & & & & & & & & & \begin{tabular}{|l|l} 
& 1 \\
\end{tabular} & 10 & & & 0 \\
\hline & 3 & & & 7 & & 4 & 6 & & 86 & 40 & 12 & 36 & 40 & & & 30 & 25 & 60 & 83 & 48 & 83 & 15 & \begin{tabular}{|l|l}
29 & 3 \\
\end{tabular} & 35 & 55 & 50 & 37 \\
\hline \multirow[t]{2}{*}{$a r$} & & & & & & 4 & & & 9 & 0 & & & 0 & & & 6 & & 16 & 0 & & 0 & 6 & 4 & 4 & 0 & & 0 \\
\hline & 57 & & 4 & 9 & & 47 & 65 & 9 & 69 & 60 & 41 & 92 & 25 & 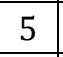 & 2 & 98 & 0 & 75 & 33 & 53 & 80 & 25 & \begin{tabular}{l|l}
60 & 5 \\
\end{tabular} & 90 & 70 & 60 & 67 \\
\hline \multirow{2}{*}{ Apr } & & & & & & 4 & & & 9 & & & & & & & & & & & & 0 & & & & & & 0 \\
\hline & 58 & & 4 & & & 8 & & & & 58 & & 43 & 3 & & & & 63 & 99 & 3 & 60 & $64:$ & & & 98 & 0 & 50 & 60 \\
\hline & 59 & 38 & 49 & 32 & 9 & 49 & 29 & 5 & 35 & 0 & 0 & & 0 & 0 & 0 & 10 & 8 & 3 & 0 & 0 & 0 & 10 & 10 & 6 & 0 & 0 & 0 \\
\hline & 63 & 5 & 46 & 91 & 64 & 75 & 27 & 51 & 2 & 66 & 22 & 23 & 7 & 9 & 3 & 50 & 51 & 25 & 58 & 92 & 88 & 92 & \begin{tabular}{|l|l}
21 & 7 \\
\end{tabular} & 75 & 68 & 56 & 70 \\
\hline \multirow{2}{*}{ Jun } & 78 & & 5 & 9 & & 66 & 32 & 2 & 20 & & & & 0 & & 0 & 11 & & 5 & & & 0 & -1 & & 6 & & & 0 \\
\hline & 67 & & & & & & & & 0 & 75 & 4 & 35 & 93 & & 0 & & 60 & 43 & 90 & 85 & 80 & \begin{tabular}{|l|}
58 \\
\end{tabular} & \begin{tabular}{|l|l}
25 & 1 \\
\end{tabular} & 15 & 56 & 69 & 45 \\
\hline & 43 & 56 & 69 & 47 & & 62 & 26 & 25 & 21 & 0 & 0 & & $\Omega$ & & 0 & 10 & 8 & & $\Omega$ & & 0 & \begin{tabular}{|l|}
9 \\
\end{tabular} & 4 & 6 & $0 \mid$ & 0 & 0 \\
\hline & 56 & 8 & 7 & 15 & 9 & 23 & 49 & 48 & 59 & 66 & 43 & 31 & 63 & 43 & 6 & 9 & 44 & 25 & 50 & $\begin{array}{ll}60 \\
\end{array}$ & $\begin{array}{ll}62 \\
\end{array}$ & \begin{tabular}{|l|}
90 \\
\end{tabular} & \begin{tabular}{|l|l|l|}
97 & \\
\end{tabular} & 64 & \begin{tabular}{|l|}
89 \\
\end{tabular} & 67 & 54 \\
\hline \multirow{2}{*}{ Aug } & 56 & & 7 & & & 6 & & & 23 & & 0 & & & & 0 & & & 3 & & & 0 & 2 & & 2 & & 0 & 0 \\
\hline & 34 & & & & & 73 & 78 & & 26 & 22 & 40 & 38 & 9 & & 0 & 55 & 63 & \begin{tabular}{|l|}
88 \\
\end{tabular} & 49 & 80 & 83 & \begin{tabular}{|l|}
29 \\
\end{tabular} & \begin{tabular}{|l|l|l}
57 & 5 \\
\end{tabular} & 59 & 57 & 67 & 45 \\
\hline \multirow[b]{2}{*}{ Sep } & 43 & & 5 & 33 & & 59 & 25 & & 25 & & & & & & 0 & 15 & & & & & & \begin{tabular}{|l|} 
\\
\end{tabular} & & 3 & o & 0 & 0 \\
\hline & \begin{tabular}{|l|}
23 \\
\end{tabular} & 39 & 67 & 81 & 34 & 86 & 72 & 98 & 40 & 76 & 47 & 30 & 25 & 8 & 7 & 20 & 39 & 93 & 51 & 95 & 55 & \begin{tabular}{|l|l|}
90 \\
\end{tabular} & \begin{tabular}{|l|l|}
90 & 3 \\
\end{tabular} & 94 & 41 & 49 & 80 \\
\hline & 56 & 6 & 35 & 35 & 52 & 67 & 28 & 2 & 18 & 0 & 0 & 0 & 0 & 0 & 0 & 6 & 8 & 5 & 0 & 0 & 0 & 4 & \begin{tabular}{|l|}
5 \\
\end{tabular} & 4 & 0 & 0 & 0 \\
\hline & 45 & & 53 & 22 & & 75 & 42 & 4 & 86 & 84 & 82 & 17 & 9 & 8 & 5 & 25 & 99 & 54 & 63 & 80 & \begin{tabular}{l|l}
42 & 8 \\
\end{tabular} & \begin{tabular}{|l|l|}
88 \\
\end{tabular} & \begin{tabular}{|l|l|}
90 & 9 \\
\end{tabular} & 93 & 45 & 41 & 56 \\
\hline \multirow{2}{*}{ Nov } & 78 & 56 & 63 & 56 & & 64 & 26 & & 21 & \begin{tabular}{l|} 
\\
\end{tabular} & & & & & 0 & & & & 0 & & 0 & 6 & \begin{tabular}{|l|}
10 \\
\end{tabular} & 2 & \begin{tabular}{l|l|} 
\\
\end{tabular} & 0 & 0 \\
\hline & 56 & 60 & 45 & 0 & 55 & 30 & 9 & 69 & 60 & 4 & 13 & 33 & 3 & 36 & 3 & 13 & 30 & 5 & 80 & 31 & 50 & 70 & \begin{tabular}{|l|l|}
85 & 8 \\
\end{tabular} & 80 & 56 & 43 & 45 \\
\hline \multirow[b]{2}{*}{ jec } & 45 & 56 & \begin{tabular}{|l|}
78 \\
\end{tabular} & 56 & 65 & 57 & 26 & 21 & 25 & 1 & 0 & 0 & 0 & 0 & 0 & 3 & 8 & 5 & 1 & 6 & 4 & \begin{tabular}{|l|}
6 \\
\end{tabular} & \begin{tabular}{|l|}
1 \\
\end{tabular} & 3 & 0 & 0 & 0 \\
\hline & \begin{tabular}{|l|}
32 \\
\end{tabular} & 45 & 67 & 3 & 14 & 19 & 49 & 67 & 45 & 38 & 38 & \begin{tabular}{|l|}
92 \\
\end{tabular} & 2 & 7 & 28 & 0 & 50 & 54 & 5 & 48 & \begin{tabular}{l|l}
45 \\
\end{tabular} & 95 & \begin{tabular}{l|l}
0 & 2
\end{tabular} & 40 & 37 & 45 & 23 \\
\hline
\end{tabular}

Table 1: Monthly variations in elemental content on flyash sample collected at TTPS (Jan 2011-Dec2017).

The table 1 shows standard level of some conventional environmental air pollutants and their monthly variations in the elemental content of flyash samples in AngulTalcher Industrial Areas from Jan 2011 to Dec 2017. The percentage of $\mathrm{SiO}_{2}$ was maximum in the atmosphere during mid-summer and the percentage of $\mathrm{Al}_{2} \mathrm{O}_{3}$ was maximum in the month of September. $\mathrm{Fe}_{2} \mathrm{O}_{3}$ level was found to be maximum during March 2011. Similarly, 
$\mathrm{B}[\mathrm{a}] \mathrm{P}$ content was maximum in the month of January and no significant pattern of distribution of $\mathrm{MnO}, \mathrm{P}_{2} \mathrm{O}_{5}$ and $\mathrm{K}_{2} \mathrm{O}$ were observed in samples of flyash collected in the year (2011-2017). PAHs such as B[a]P, and other organic pollutants which are unwanted chemical pollutants.

In our study we collected the monthly variation of elemental content in flyash samples at TTPS from the year Jan 2011 to Dec 2017. The result of our present study showed that $\mathrm{SiO}_{2}, \mathrm{Al}_{2} \mathrm{O}_{3}, \mathrm{Fe}_{2} \mathrm{O}_{3}$ content vary in samples of different locations, the percentage of the $\mathrm{SiO}_{2}$ content was maximum in the atmosphere during mid-summer, the percentage of $\mathrm{Al}_{2} \mathrm{O}_{3}$ was found to be maximum in the month of September, and $\mathrm{Fe}_{2} \mathrm{O}_{3}$ was found to be maximum during the month of March. Similarly, B[a]P content $\left(\mu \mathrm{g} / \mathrm{m}^{3}\right)$ was maximum among the flyash collected from electrostatic precipitators. No significant pattern of distribution of $\mathrm{MnO}, \mathrm{P}_{2} \mathrm{O}_{5}$ and $\mathrm{K}_{2} \mathrm{O}$ were observed in different stages of ash collected. The concentration of the different flyash samples found to vary during the year 2011-2017 due to high as well as low rate of pollution respectively. Similarly others oxides showed a random distribution pattern in different stages of collected sample of flyash (Table 1). In Table 2, the concentrations of various trace elements in flyash like $\mathrm{Pb}$, $\mathrm{Zn}, \mathrm{Cu}, \mathrm{Cd}, \mathrm{Ni}$, Co etc were measured $(\mu \mathrm{g} / \mathrm{kg})$ at different sampling points in Angul-Talcher industrial area. Among the measured metals, $\mathrm{Pb}$ and $\mathrm{Cd}$ had the highest concentrations at the TTPS area sampling station. These particles found to be dominated by finer particles; containing unborn carbon particles (soot) indicating incomplete combustion of coal. Due to the large surface area, the soot particles known to act as a carrier for toxic organics e.g. $\mathrm{B}[\mathrm{a}] \mathrm{P}$ and other toxic metals which may enters the biological system of animals and humans leading to various health hazards. Sometimes due to extremes seasonal variation concentration of the trace elements vary from high in winter to low in summer possessing serious environmental concern due to atmospheric fallouts (Table 2).

\begin{tabular}{|c|c|c|c|c|c|c|c|c|c|c|c|c|c|c|c|c|c|c|}
\hline \multirow{2}{*}{ Year } & \multicolumn{3}{|c|}{$\mathbf{P b}$} & \multicolumn{3}{|c|}{ Zn } & \multicolumn{3}{|c|}{$\mathrm{Cu}$} & \multicolumn{3}{|c|}{ Cd } & \multicolumn{3}{|c|}{$\mathrm{Ni}$} & \multicolumn{3}{|c|}{ Co } \\
\hline & 1 & 2 & 3 & 1 & 2 & 3 & 1 & 2 & 3 & 1 & 2 & 3 & 1 & 2 & 3 & 1 & 2 & 3 \\
\hline 2010 & 445 & 231 & 435 & 216 & 210 & 150 & 196 & 62 & 80 & 10 & 17 & 15 & 153 & 127 & 104 & 50 & 440 & 40 \\
\hline 2011 & 217 & 198 & 387 & 159 & 90 & 85 & 100 & 196 & 72 & 17 & 15 & 8.5 & 136 & 131 & 107 & 126 & 38 & 39 \\
\hline 2012 & 256 & 286 & 289 & 168 & 106 & 98 & 97 & 107 & 56 & 10 & 12 & 7.3 & 122 & 111 & 113 & 124 & 36 & 32 \\
\hline 2013 & 378 & 365 & 346 & 179 & 121 & 77 & 85 & 97 & 68 & 5 & 7.6 & 12 & 147 & 115 & 118 & 129 & 40 & 35 \\
\hline 2014 & 298 & 276 & 256 & 154 & 147 & 135 & 78 & 74 & 42 & 7 & 17 & 9.4 & 154 & 103 & 121 & 134 & 35 & 37 \\
\hline 2015 & 446 & 457 & 423 & 138 & 133 & 122 & 69 & 149 & 66 & 14 & 8.5 & 13 & 167 & 106 & 146 & 154 & 32 & 30 \\
\hline 2016 & 432 & 463 & 452 & 129 & 137 & 128 & 78 & 136 & 69 & 30 & 9 & 17 & 178 & 109 & 157 & 156 & 36 & 50 \\
\hline 2017 & 459 & 452 & 450 & 135 & 134 & 125 & 80 & 139 & 75 & 28 & 19 & 26 & 187 & 117 & 165 & 164 & 43 & 55 \\
\hline
\end{tabular}

Table 2: Trace element concentration in flyash (in ppm) at TTPS during the year (2010-2017).

The table 2 shows standard level of the various trace elements and their concentration in the flyash samples is presented in which the values were defined as air quality standards in Angul and Talcher during the year (20102017). The presence of various particulate matter pollutants and heavy metals like $\mathrm{Pb}, \mathrm{Zn}, \mathrm{Cu}, \mathrm{Cd}, \mathrm{Ni}$, Co in the atmosphere leads to significant decrease in the air quality index and the concentration of $\mathrm{Pb}, \mathrm{Ni}$, Co were found to be maximum in the year 2017.

\section{Effects of Exposure to B[a]P on Lungs Tissue of Wistar Rats}

Morphological alterations were shown in lungs section by H\&E staining (Figure 2). Lower doses of $\mathrm{B}[\mathrm{a}] \mathrm{P}$ exposure to rats at PND28 leads to significant morphological changes having acute reaction with patent alveoli after 15 days (Figure 2b) of intratracheal instillation when compared with control lung tissues having well differentiated alveolar structures (Figure 2a). H\&E stained lungs for rats exposed to higher doses of $\mathrm{B}[\mathrm{a}] \mathrm{P}$ showed inflammatory cell infiltration in blood vessels with thickening of alveolar cells after 15 days of exposure (Figure 2). Whereas at lower doses after one month $\mathrm{B}[\mathrm{a}] \mathrm{P}$ exposure it showed extremely congested capillaries in the walls of the alveoli and also there is some infiltration by inflammatory cells in comparison to normal (Figure 2d). At higher doses and longer period of $\mathrm{B}[\mathrm{a}] \mathrm{P}$ exposure lungs showed damaged in alveolar structures and enlarged lung compartment in comparison to normal control (Figure 2e). 


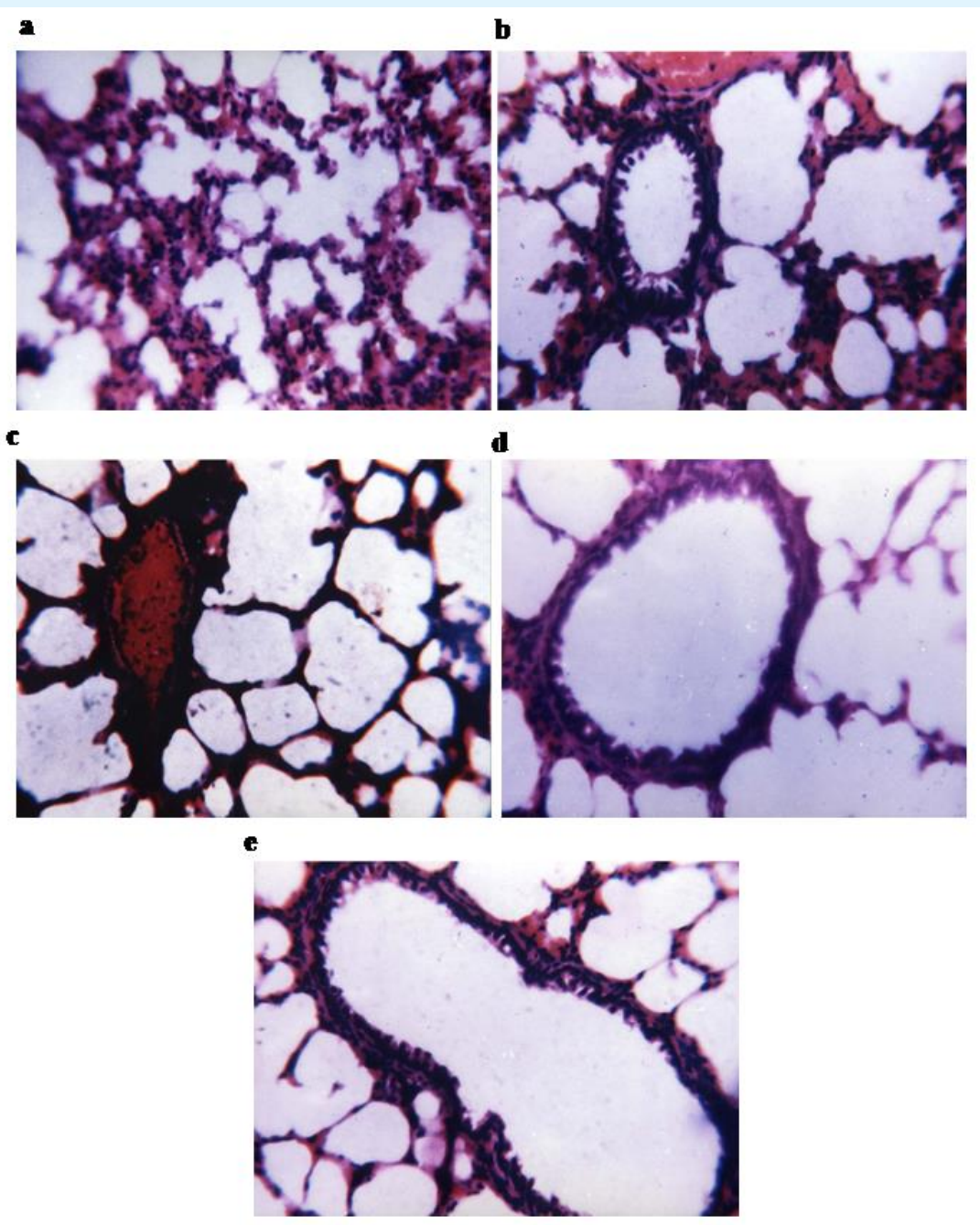

Figure 2

Figure 2: Lungs, Histopathological analysis of lungs tissue sections of wistar rats after intratracheal instillation of $\mathrm{B}[\mathrm{a}] \mathrm{P}$.

a. Histopathological sections of lung tissue of control groups of Wistar rats $(n=6)$ treated with normal saline, showing well differentiated alveolar structures at 100X magnification. Scale bar $=100 \mu \mathrm{m}$.

b. Histopathological sections of lung tissues of Wistar rats $(n=6)$, after 15 days of B[a]P administration (25 $\mathrm{mg} / \mathrm{animal}$ ), showing acute reaction with patent alveoli leads to slight damage to the alveolar walls at $100 \mathrm{X}$ magnification. Scale bar $=100 \mu \mathrm{m}$.

c. Histopathological sections of lungs tissue of Wistar rats $(n=6)$, after 30 days of $\mathrm{B}[\mathrm{a}] \mathrm{P}$ administration $(25$ $\mathrm{mg} /$ animal), showing thickening of alveolar cells, severe damage to alveolar sacs leading to decline in lung functions at 100X magnification. Scale bar $=100 \mu \mathrm{m}$.

d. Histopathological sections of lungs tissues of Wistar rats $(n=6)$, after 15 days of administration of a higher dose of $\mathrm{B}[\mathrm{a}] \mathrm{P}$ (50 mg/animal), revealed proliferative lesions, composed of bronchiolar cells forming isolated island in lungs parenchyma at $100 \mathrm{X}$ magnification. Scale bar $=100 \mu \mathrm{m}$.

e. Histopathological sections of lungs tissue of Wistar rats $(n=6)$, after 30 days of administration of a higher dose of $\mathrm{B}[\mathrm{a}] \mathrm{P}(50 \mathrm{mg} / \mathrm{animal})$ showed interstitial fibrosis with chronic inflammation in the alveolar space containing alveolar macrophages and lungs damage at 100X magnification. Scale bar=100 $\mu \mathrm{m}$. 


\section{Effects of B[a]P on Testis of Wistar Rats}

Wistar rats exposed to lower dose of B[a]P at PND28 for 15 days showed no changes in tubular and intertubular parameters in the testis of adult rats in comparison to control (Figure 3b). After 15 days of treatment in higher doses of $\mathrm{B}[\mathrm{a}] \mathrm{P}$ exposure, the reduction in tubular area was observed in H\&E stained testis with increase lumen diameter (Figure 3c). However, in the higher dose of $\mathrm{B}[\mathrm{a}] \mathrm{P}$ exposure groups exhibited an increased in tunica propria layer with lumen diameter as compared to that of control groups administered with DMSO $(<0.1 \%)$ only (Figure $3 a)$.

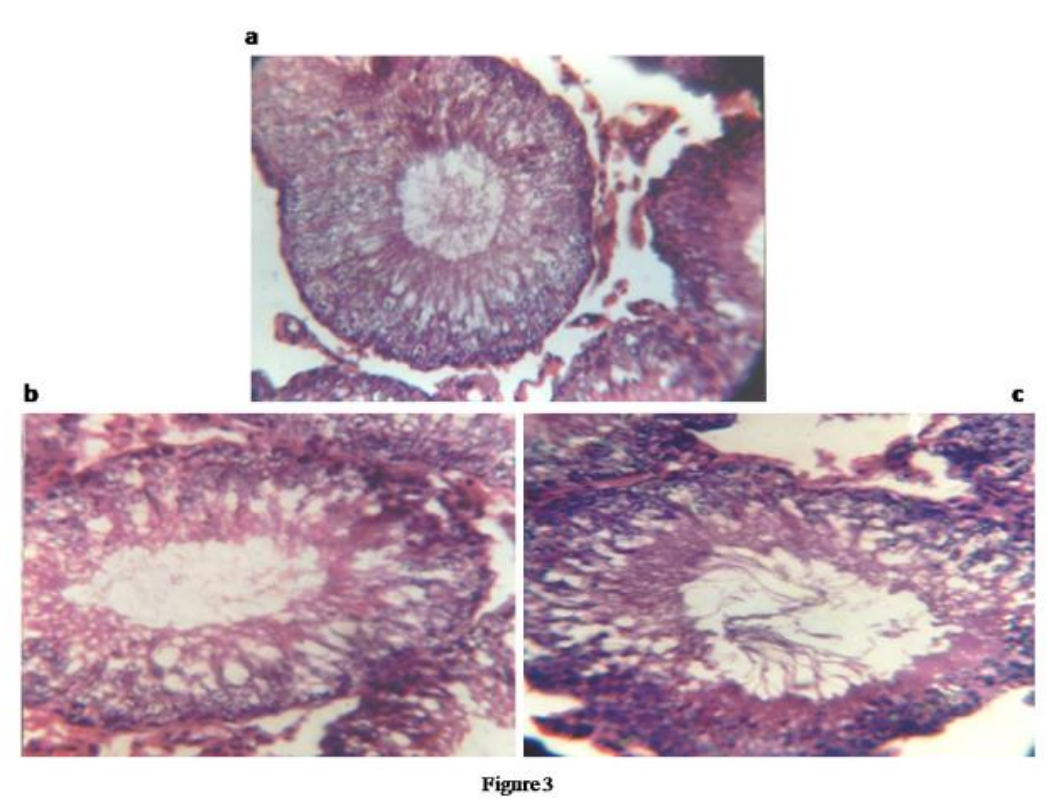

Figure 3: Testis, Histopathological analysis of testis sections of wistar rats after intraperitonial administration of B[a]P:

a. Histopathological sections of Testis of control groups of Wistar rats $(n=6)$, after intraperitonial instillation of DMSO $(<0.1 \%)$ only, showing normal histological structure of active mature functioning seminiferous tubules associated with complete spermatogenic series. Magnification 100X, Scale bar $=100 \mu \mathrm{m}$.

b. Histopathological sections of testis of adult Wistar rats $(n=6)$, after intraperitonial administration of $B[a] P$ (25 $\mathrm{mg} / \mathrm{animal}$ ) at PND28 (dissolve in DMSO) showed marked degeneration of most seminiferous tubules with absence of spermatogenic series in tubular lumen and congestion in testis blood vessels after 15 days. Magnifications 100X, Scale bar $=100 \mu \mathrm{m}$.

c. Histopathological sections of testis of adult Wistar rats $(n=6)$ showed reduction in tubular area in H\&E stained testis with increase lumen diameter in higher doses of $\mathrm{B}[\mathrm{a}] \mathrm{P}$ exposure after intraperitonial administration of $\mathrm{B}[\mathrm{a}] \mathrm{P}(50$ $\mathrm{mg}$ /animal) at PND28. It also showed marked degeneration of most of the somniferous tubules with absence of spermatogenic series in tubular lumen and congestion in testis blood vessels after 15 days. Magnifications 100X, Scale bar $=100 \mu \mathrm{m}$.

\section{Effects of Exposure to Particulate Air Pollutants on Human}

The primary purpose of this study was to obtain plain $\mathrm{x}$-ray reports of clinically healthy person and permanent residents of either Angul or Talcher area with the control from Chhendipada (S1) area with a total of 12 volunteer participant's ages ranging from 20 to 60 years for the present study. We observed mild bronchial wall thickening in 03 out of 12 , central airways in 4 of 10 , air trapping in 2 of 15, and pulmonary nodules in 2 of 20 as interpreted the radiographs by radiologists from SCB Medical College and hospital, Cuttack. Representative 
chest X-ray reports shown in Fig.4b-e with hyperinflation and linear markings in exposed individuals as compared to normal (Figure 4a). Mostly the abnormalities in chest $\mathrm{X}$-rays were seen with alveolar duct inflammation in volunteers residing nearby areas of TTPS (Figure 4e).

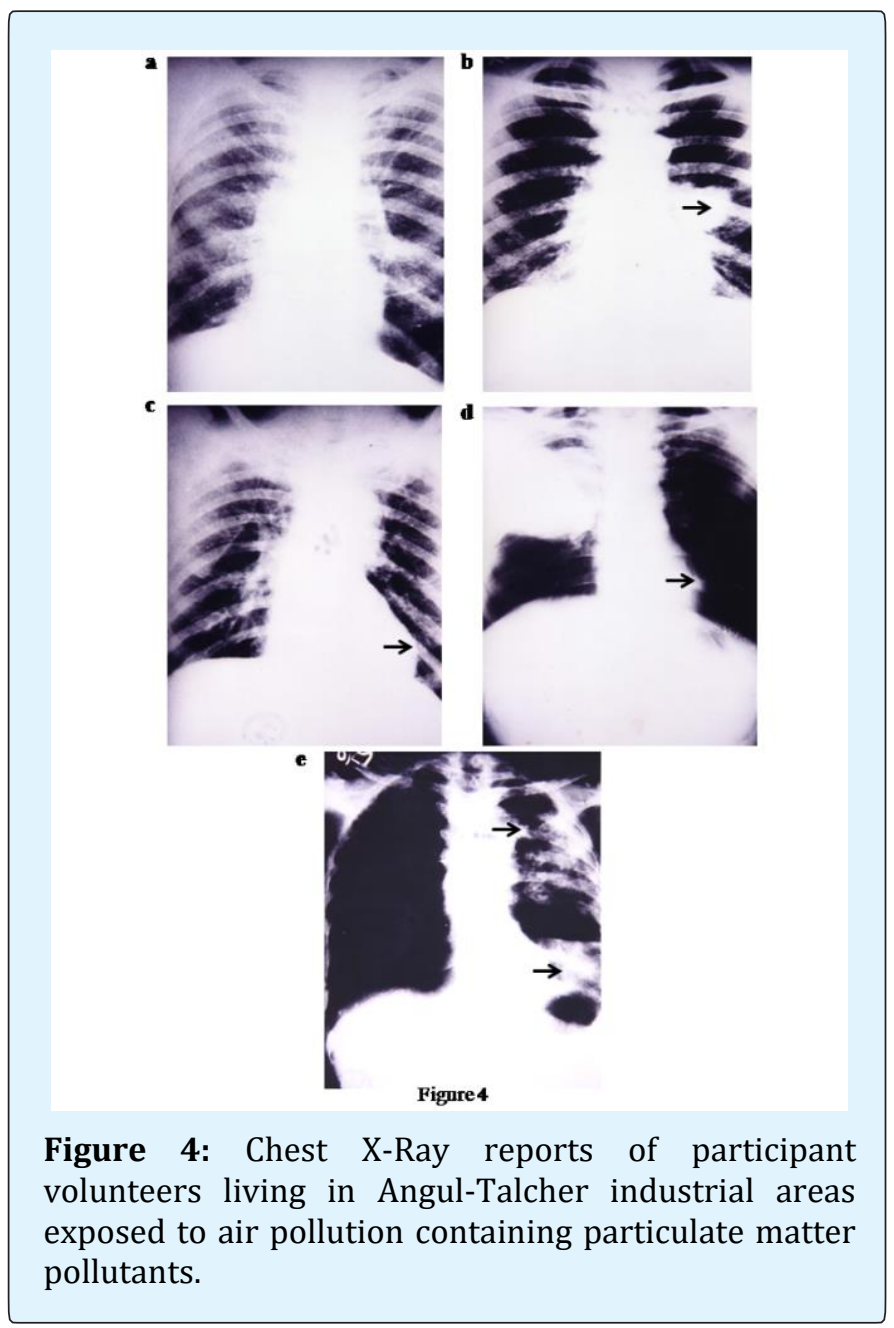

X-ray beams pass through the body, and they are absorbed in different amounts depending on the density of the material they pass through. Hence, the dense materials, such as bone and metal, show up as white on Xrays. The air in lungs shows up as black. Fat and muscle appear as shades of gray.

a. The frontal chest X-ray radiograph image of lungs of an individual living in Chhendipada area showing normal lungs structure with normal alveolar morphology indicating the less polluted and control zone.

b. The frontal chest X-ray radiograph image of lungs of an individual living in Angul-Talcher area showing increased linear markings and inflammation of the lungs suffering from tuberculosis.

c. The frontal chest X-ray radiograph image of lungs of an individual living in Angul-Talcher area with a lung disease called emphysema in the patient's left lung, showing reversible increase on lung compliance, total lung capacity severe inflammation (arrow) of the pulmonary airways and bronchial hyperresponsiveness leading to respiratory failure.

d. The chest X-ray radiograph image of lungs of an individual living in Angul-Talcher area suffering from Bronchitis (arrow) showing hyper-expansion of the lungs associated with chronic bronchitis, pulmonary arterial hypertension and COPD (Chronic obstructive pulmonary disease) leading to enlarged and empty lung fields and flatted out form of the diaphragm.

e. The frontal chest X-ray radiograph image of lungs of an individual living in Angul-Talcher area showing mild peribronchial thickening (left arrow) and minimal airway dilatation (right arrow) with damage to alveolar walls and leading towards formation of lungs tumour.

\section{Discussion}

Air pollution in Angul-Talcher area is predominant due to higher levels of various particulate matters in air and has recently caused several health and environmental problems [1,2]. The quality of air in TTPS is very unhealthy and most of the pollution indices, especially gaseous and particulate pollutants like fly ash are above the standard and at some year at dangerous level [8]. Moreover, reports have shown that more than $80 \%$ of air pollution in Angul-Talcher area is attributed to industrial emissions [19]. The major solid waste products are also derived as a result of power generation from thermal power plants due to incomplete combustion of pulverized coal and fossil fuels etc [20]. PAHs can severely affect the normal physiology, growth, development and behaviour $[20,24]$ in experimental animals and children [26]. Fly ash contain 10-12\% of the unburned component and these unburned carbon particles tends to increase the level of other atmospheric pollutants including gaseous pollutants and flyash containing PAHs like B[a]P [28]. B[a]P and its metabolites belong to one of the member of PAHs family. Moreover, levels of $\mathrm{B}[\mathrm{a}] \mathrm{P}$ are in the $\mu \mathrm{g} / \mathrm{kg}$ range in ambient environment (air, water, soil sediment) and foodstuffs. Exposures to these chemicals are toxic in vivo at $\mu \mathrm{g}$ amount [5]. The present study showed B[a]P exposure from all industries in Angul-Talcher area causing the major threats to atmospheric environment. 


\section{International Journal of Zoology and Animal Biology}

Atmospheric pollutants were monitored at three monitoring stations, Chhendipada, Angul and Talcher area located in Angul district of Odisha. Talcher power station measured average hourly levels of $\mathrm{SO}_{2}, \mathrm{NO}_{2}$ and PM2.5. Environmental monitoring studies reported that the levels of $\mathrm{B}[\mathrm{a}] \mathrm{P}$ tend to be higher in Talcher area than in Angul area [23]. Whereas concentration of $\mathrm{B}[\mathrm{a}] \mathrm{P}$ in air levels found to be $0.2-19.3 \mathrm{ng} / \mathrm{m}^{3}$ for urban area and 0.1 $0.2 \mathrm{ng} / \mathrm{m}^{3}$ in rural area of Talcher. B[a]P levels existed in the range of $0.1-10 \mu \mathrm{g} / \mathrm{m}^{3}$ in the rural houses of the developing countries as compared to $0.02-0.1 \mu \mathrm{g} / \mathrm{m}^{3}$ in the traffic and 20-100 ng per cigarette [19,23]. The highest environmental concentrations of $\mathrm{B}[\mathrm{a}] \mathrm{P}$ are found in soil samples and usually range from $0.8 \mathrm{ng} \mathrm{kg}-1$ to 100 $\mathrm{mg} \mathrm{kg}^{-1}$. B[a]P content in food stuffs and plants is between 0.1 and $150 \mu \mathrm{g} \mathrm{kg}^{-1}$, the air has a concentration of around 1.3 to $500 \mathrm{ng} / \mathrm{m}^{-3}$ and drinking water generally contains 2.5 to $9 \mathrm{ng} / \mathrm{L}^{-1}$. According to the available data, the main toxic effects of exposure to air pollutants.

In the present study we have examined the acute health impacts of particulate pollutants on both humans as well as animals living near major industrial areas like Angul-Talcher area. The pollution rate in these areas were evaluated different parameters for the year 2010-2017, which showed maximum percentage (58\%) pollution rate from power station (Figure 1). This led us to use the proximity to source methods to classify exposure for the population living around Angul-Talcher areas. The proximity approach was particularly in assessing health effects around industrial complexes in both human and animals [30]. In our studies we found monthly variation in elemental content in fly ash as samples collected at TTPS for the year (2010-2017) and the trace element concentration were found to be maximum in fly ash $(\mathrm{Pb}$ and Cd) at TTPS during the year (2016-2017). The trace metals present in fly ash samples were measured at the lowest concentrations at the residential areas. The $\mathrm{B}[\mathrm{a}] \mathrm{P}$ content was found to be maximum in fly ash collected from electrostatic precipitators installed in highly polluted areas like TTPS. No significant changes were observed in distribution pattern of $\mathrm{Al}_{2} \mathrm{O}_{3}, \mathrm{Fe}_{2} \mathrm{O}_{3}$ and $\mathrm{Na}_{2} \mathrm{O}$ at different stages of fly ash collected from S1 sites. Whereas other oxides showed a random distribution pattern in different stages of sample of fly ash collected in these areas. It was found that the pollution level was increasing month wise with maximum, minimum and average values of monitoring data from 2011-2017, which showed a clear demarcation at two locations of AngulTalcher area [23]. The concentration of particulate matter with respect to $\mathrm{B}[\mathrm{a}] \mathrm{P} \quad(250-480 \mu \mathrm{g} / \mathrm{mg})$ and its metabolites are found to be harmful to animals and human.

Our previous studies on animal model showed significant histopathological changes in brain [31]. In the present study, $\mathrm{B}[\mathrm{a}] \mathrm{P}$ proved effective in inducing significant incidence of alveolar macrophages which result in the permanent damage to the lungs as supported by studies on gaseous and particle pollution causing synergistic effect of pulmonary damage [32]. Also previous studies showed significant changes in the pulmonary system with expansion of alveolar walls and desquamation of epithelial cells due to PAHs exposure through milk [33]. Animals exposed over longer periods to the levels some PAHs may developed lung cancer from inhalation, stomach cancer from ingesting PAHs in food, and skin cancer from skin contact $[34,35]$. The behavioral impairments resulting from postnatal $\mathrm{B}[\mathrm{a}] \mathrm{P}$ exposure are potentially long-lasting [36,37].

Similarly, significant changes in the chest X-ray report was found on exposure to air pollutants like different particulate matter e.g. B[a]P in Angul-Talcher areas. In our present study, chest X-ray report showed that exposure to particulate matter causes severe asthma, bronchitis, tuberculosis etc that might enhance the lungs cancer, in human respiratory system. The mechanisms of human lung carcinogenesis mediated by PAHs was studied for the leading cause of cancer-related death [38]. The enhancement of the respiratory illness in the surrounding villages of Angul-Talcher may be due to the action of $\mathrm{B}[\mathrm{a}] \mathrm{P}$, found in the atmospheric particulate matter, although the effects of the trace elements cannot be excluded. Mixtures of particulate matter are also known to cause skin irritation, inflammation and other skin diseases $[39,40]$.

According to our present study concentrations of $\mathrm{B}[\mathrm{a}] \mathrm{P}$ have been exceeding the annual limit value of 1 $\mathrm{ng} / \mathrm{m} 3$, in some localities to several fold in different year. The levels of air pollution, and especially effects of $\mathrm{B}[\mathrm{a}] \mathrm{P}$, leads to significant increase in respiratory morbidity, asthma bronchiole, and cardiovascular mortality in humans as well as animals. The health and biological effect studies clearly demonstrate that under the present environmental conditions, the health of the population in the Angul-Talcher area is severely impaired and will likely remain so for a significant period of time (2012-2014). This study is unique because for the first time, we used to analyse the relationship between air pollution and their hazardous effects on biological system. 


\section{International Journal of Zoology and Animal Biology}

\section{Conclusion}

According to our study report, at all the monitored locations of the area for the year 2011 to 2017, the atmospheric particulate pollutants like $\mathrm{Pb}, \mathrm{Ni}, \mathrm{Co}, \mathrm{SO}_{2}, \mathrm{CO}$, and $\mathrm{Hg}$ present in the air are main sources of pollution emitted due to industrial processes. The annual average value of PM at all monitoring location of coal field area exceeded the limit. Whereas, in NALCO Nagar and TTPS area all monitoring stations were within the limit, except at MCL, Angul (i.e,58 $\mu \mathrm{g} / \mathrm{m}^{3}$ ). The maximum average value of PM was observed on the month of November, 2014 at coal field station, Talcher. The flyash containing PAHs e.g. $\mathrm{B}[\mathrm{a}] \mathrm{P}$ are absorbed on the surface of the soot particle and the large surface area of the fine particle contributing to the high rate of the reaction in biological system. These findings provide evidence for the association between industrial pollution and vulnerability to respiratory diseases in Angul-Talcher areas.

\section{Ethics Approval and Consent to Participate}

The Ethics Committee of the Ravenshaw University, Cuttack (Regd. No.1927/Go/Re/S/16/CPCSEA) has approved the present study.

\section{Conflict of Interest}

The authors have no competing interests to declare.

\section{Acknowledgments}

This study was supported by research grant to MP from (BRNS, Mumbai, 37(1)/14/27/2015/BRNS), Department of Science and Technology (DST), Odisha (No.27562800402014/20-665) and DRDO, New Delhi (No. O/o DG (TM) /81/48222/LSRB-294/PEE\&BS/2017). The funds supported to Lipsa Das (UGC-RGNF National Fellow-RGNF-2015-17-SC-ORI-10772) awarded by UGC, Govt. of India.

\section{References}

1. Panda S (2007) Environment and Ecology. $2^{\text {nd }}$ (Edn.), Vrinda Publication, Pvt Ltd, Delhi.

2. Dey AK (2012) Environmental Chemistry. $7^{\text {th }}$ (Edn.), New age international Pvt Ltd, New Delhi.
3. Hall JV, Brajer V, Lurmann FW (2010) Air pollution, health and economic benefits-Lessons from 20 years of analysis. Ecol Econ 69: 2590-2597.

4. Kampa M, Castanas E (2008) Human health effects of air pollution. Environ Pollut 151(2): 362-367.

5. Makri A, Stilianakis NI (2008) Vulnerability to air pollution health effects. Int J Hyg Environ Health 211(3-4): 326-336.

6. Jacobson MZ (2009) Review of solutions to global warming, air pollution, and energy security. Energy Environ Sci 2: 148-173.

7. Rumana HS, Sharma RC, Beniwal V, Sharma AK (2014) A retrospective approach to assess human health risks associated with growing air pollution in urbanized area of Thar Desert, Western Rajasthan, India. J Environ Health Sci Eng 12(1): 23.

8. Moharana JK, Nanda PM, Garnaik BK (2013) Eutrofication due to industrialization in AngulTalcher industrial complex of Odisha. International Journal of Science Environment and Technology 2(1): 20- 27.

9. Mukherjee A, Agrawal M (2018) A Global Perspective of Fine Particulate Matter Pollution and Its Health Effects. Rev Environ Contam Toxicol 244: 5-51.

10. Hussein I, Abdel S, Mansour SM (2016) A review on polycyclic aromatic hydrocarbons: Source, environmental impact, effect on human health and remediation. Egyptian Journal of Petroleum 25(1): 107-123.

11. Hajiloo F, Hamzeh S, Gheysari M (2018) Impact assessment of meteorological and environmental parameters on PM2.5 concentrations using remote sensing data and GWR analysis (Tehran). Environ Sci Pollut Res Int.

12. Roberts AL, Lyall K, Hart JE, Laden F, Just AC, et al. (2013) Perinatal air pollutant exposures and autism spectrum disorder in the children of nurses' health study II participants. Environ Health Perspect 121(8): 978-984.

13. Goncharov A, Haase RF, Santiago RA, Morse G, McCaffrey RJ, et al. (2008) High serum PCBs are associated with elevation of serum lipids and 


\section{International Journal of Zoology and Animal Biology}

cardiovascular disease in a native American population. Environ Res 106(2): 226-239.

14. Johannson KA, Vittinghoff E, Lee K, Balmes JR, Ji W, et al. (2014) Acute exacerbation of idiopathic pulmonary fibrosis associated with air pollution exposure. Eur Respir J 43(4): 1124-1131.

15. Nelson JW, Hatch EE, Webster TF (2010) Exposure to polyfluoroalkyl chemicals and cholesterol, body weight, and insulin resistance in the general U.S. population. Environ Health Perspect 118(2): 197-202.

16. Vermaelen K, Brusselle G (2013) Exposing a deadly alliance: Novel insights into the biological links between COPD and lung cancer. Pulm Pharmacol Ther26 (5): 544-554.

17. Chen B, Kan H (2008) Air pollution and population health: A global challenge. Environ Health Prev Med 13(2): 94-101.

18. Yuxi Z, Cheng X, Zhi F, Yaqin S, Jie Z, et al. (2017) Associations between total mercury and methyl mercury exposure and cardiovascular risk factors in US adolescents. Environmental Science and Pollution Research 25(7): 6265-6272.

19. Bibekananda B, Akhila KS (2010) Action plan for abatement of pollution in critically polluted industrial clusters (Angul-Talcher area, Orissa).

20. Julie P, Frederic C, Nathalie G, Herve N, Guillaume S, et al. (2013) Neurobehavioral Toxicity of a Repeated Exposure (14Days) to the Airborne Polycyclic Aromatic Hydrocarbon Fluorene in Adult Wistar Male Rats. Plos One 8(8): e71413.

21. Adil AW, Ariana AZ (2015) Research Health impacts from living near a major industrial park in Oman. Public Health 15: 524.

22. Rizwan R, Gurdeep S (2010) Impact of industrial development on surface water resources in Angul region of Orissa. International Journal of Environmental Sciences 1(4): 514-522.

23. Lovett GM, Tear TH, Evers DC, Findlay SE, Cosby BJ, et al. (2009) Effects of air pollution on ecosystems and biological diversity in the eastern United States. Ann N Y Acad Sci 1162: 99-135.
24. Rabindra KS (2016) Effect of ambient air and water pollution in Talcher: Angul industrial area: A case study. International Journal of Multidisciplinary Research and Development Volume 3(2): 260-263.

25. Schroeder H (2011) Developmental brain and behaviour toxicity of air pollutants: A focus on the effects of Polycyclic Aromatic hydrocarbons (PAHs). Crit Rev Environ Sci Technol 41(22): 2026-2047.

26. Perera FP, Rauh V, Whyat RM, Tsai WY, Tang D, et al. (2006) Effect of prenatal exposure to air borne polycyclic aromatic hydrocarbons on neurodevelopment in the first 3 years of life among inner-city children. Environ Health Perspect 114(8): 1287-1292.

27. Zhou N, Cui Z, Yang S, Han X, Chen G, et al. (2014) Air pollution and decreased semen quality: A comparative study of Chongqing urban and rural areas. Environ Pollut 187: 145-152.

28. Mellouki A, George C, Chai F, Mu Y, Chen J, et al. (2016) Sources, chemistry, impacts and regulations of complex air pollution: Preface. J Environ Sci (China) 40: 1-2.

29. Bentayeb M, Simoni M, Norback D, Baldacci S, Maio S, et al. (2013) Indoor air pollution and respiratory health in the elderly. J Environ Sci Health A Tox Hazard Subst Environ Eng 48: 1783-1789.

30. Gorai AK, Tuluri F, Tchounwou PB (2014) A GIS based approach for assessing the association between air pollution and asthma in New York state, USA. Int J Environ Res Public Health 11(5): 4845-4869.

31. Patel B, Das SK, Das S, Das L, Patri M (2016) Neonatal exposure to $\mathrm{B}[\mathrm{a}] \mathrm{P}$ induces oxidative stress causing altered hippocampal cytomorphometry and behaviour during early adolescence period of male Wistar rats. International Journal of Development Neuroscience 50: 7-15.

32. Rylander R, Bergstrom R (1973) Particles and $\mathrm{SO}_{2}$ Synergistic effect of pulmonary damage." In proceedings of the Third International Clean Air Congress, Dusseldorf, VDI Verlag pp: A23-A25.

33. Zanieri L, Galvan P, Checchini L, Cincinelli A, Lepri L, et al. (2007) Polycyclic aromatic hydrocarbons (PAHs) in human milk from Italian women: influence 


\section{International Journal of Zoology and Animal Biology}

of cigarette smoking and residential area. Chemosphere 67(7): 1265-1274.

34. Radim JS, Miroslav D, Helena L, Pavel R, Andrea R, et al. (2013) The European Hot Spot of B[a]P and PM2.5 Exposure-The Ostrava Region, Czech Republic: Health Research Results. ISRN Public Health 2013: 12.

35. Chen C, Tang Y, Jiang X, Qi Y, Cheng S, et al. (2012) Early postnatal Benzo[a]pyrene exposure in SpragueDawley rats causes persistent neurobehavioral impairments that emerge postnatally and continue into adolescence and adulthood. Toxicol Sci 125(1): 248-261.

36. Saunders CR, Das SK, Ramesh A, Shockley DC, Mukherjee S (2006) B [a]P-induced acute neurotoxicity in the F-344 rat: role of oxidative stress. J Appl Toxicol 26(5): 427-438.
37. Moorthy B, Chu C, Carlin DJ (2015) Polycyclic Aromatic Hydrocarbons: From Metabolism to Lung Cancer. Toxicol Sci 145(1): 5-15.

38. Cohen AA, Buechley S, Heiderscheit RW, Shy LT (1972) Asthma and air pollution from a coal fuelled power plant. Am J Public Health 62(9): 1181-1188.

39. Bentov Y, Kordysh E, Hershkovitz R, Belmaker I, Polyakov M, et al. (2006) Major congenital malformations and residential proximity to a regional industrial park including a national toxic waste site: an ecological study. Environ Health 5: 8.

40. WangY, Zhao H, Wang T, Liu X, Ji Q, et al. (2019) Polycyclic aromatic hydrocarbons exposure and hematotoxicity in occupational population: A twoyear follow-up study. Toxicol Appl Pharmacol 378: 114622. 